\title{
Intestinal, hepatic, splanchnic and hindquarter amino acid and metabolite partitioning during an established Trichostrongylus colubriformis infection in the small intestine of lambs fed fresh Sulla (Hedysarum coronarium)
}

\author{
Emma N. Bermingham ${ }^{1}$, Warren C. McNabb ${ }^{1}$, Ian A. Sutherland ${ }^{2}$, Bruce R. Sinclair ${ }^{1}$, Bryan P. Treloar ${ }^{1}$ \\ and Nicole C. Roy ${ }^{1} *$ \\ ${ }^{1}$ Food, Metabolism \& Microbiology Section, Food \& Health Group, AgResearch Grasslands, Palmerston North, New Zealand \\ ${ }^{2}$ Animal Health Group, AgResearch Hopkirk Research Institute, Palmerston North, New Zealand
}

(Received 15 November 2006 - Revised 25 April 2007 - Accepted 8 May 2007)

Increased partitioning of amino acids (AA) from skeletal muscle to the intestine and immune system during parasitic infection may be the cause of poor growth in parasitised animals. The effect of an established Trichostrongylus colubriformis infection (6000 L3 T. colubriformis larvae for $6 \mathrm{~d}$ ( $n$ 5) or kept as parasite-free controls $(n 6)$ ) on AA fluxes across the mesenteric-drained viscera, portal-drained viscera (PDV), liver, total splanchnic tissues (TSP) and hindquarters were determined in lambs fed fresh Sulla (Hedysarum coronarium; $800 \mathrm{~g} \mathrm{DM} / \mathrm{d}$ ) $48 \mathrm{~d}$ post-infection. The lambs were infused with $\rho$-aminohippuric acid (PAH; $723 \mathrm{mg} / \mathrm{h}$ ) into the mesenteric vein for $8 \mathrm{~h}$ to measure TSP plasma flow. Concurrently, indocyanine green (ICG; $14.6 \mathrm{mg} / \mathrm{h}$ ) was infused into the abdominal aorta to measure plasma flow across the hindquarters. Blood was continuously collected from the mesenteric, portal and hepatic veins, vena cava and the mesenteric artery and plasma harvested. PAH, ICG, AA, metabolite and insulin concentrations were measured. Intestinal worm burdens on day 48 post-infection were higher in the infected lambs $(P<0.05)$. Plasma flows across the tissue beds were unaffected by parasitic infection $(P>0 \cdot 10)$. There was a $28 \%$ reduction in the release of AA from the PDV of infected lambs $(P<0 \cdot 05)$. The uptakes of most AA were similar in the liver; however, there was increased uptake $(P<0 \cdot 10)$ of AA by the TSP of infected lambs. Despite this reduction in AA availability at the liver, there was no effect of parasitic infection on AA uptake across the hindquarters $(P<0 \cdot 05)$.

Amino acid and metabolite partitioning: Trichostrongylus colubriformis: Intestine: Liver: Hindquarters

Shifts in nutrient utilisation and partitioning within the tissues of the body, with an emphasis on those required to repair damaged tissues or mount an immune response, are major causes of the reduction of animal productivity observed in intestinal parasitic infection ${ }^{1-3}$. Yu et al. ${ }^{4}$ noted that parasitic infection in the small intestine increased leucine oxidation and protein turnover in the gastrointestinal tract. This resulted in a reduction in leucine release in the portal drainage during parasitic infection and potentially a lesser amount of amino acids (AA) available for productive tissues such as skeletal muscle. This may account for part of the decrease in animal production with parasitic infection. However, there is no information available on the partitioning of AA between the intestine, liver and hindquarters in parasitised lambs. The liver of healthy animals removes considerable amounts of AA from the portal circulation ${ }^{5,6}$. Additionally, protein synthesis rates of the liver increase during parasitic infection of the small intestine $^{7-10}$. Therefore, it is possible that the already high metabolic requirement of the healthy total splanchnic tissues (TSP; portal-drained viscera (PDV) and liver) increases with parasitic infection at the expense of skeletal muscle growth ${ }^{8}$, and this is often a period when feed intake is also reduced ${ }^{11}$.
It is hypothesised that the TSP of animals with an intestinal parasite burden will require additional AA in order to repair the damage caused to the small intestine by Trichostrongylus colubriformis and to mount an immune response against infection, and that some of these AA will be sourced from the skeletal muscle of the hindquarters. The objective of the present study was to quantify the partitioning of AA between the TSP and hindquarters during a parasitic infection. This was achieved by measuring the net flux of AA and associated metabolites and insulin across the mesenteric-drained viscera (MDV; small intestine), PDV (rumen, MDV, large intestine, pancreas, spleen), liver and hindquarters. The present paper forms part of a larger study determining the effects of parasitic infection on whole-body and tissue AA kinetics ${ }^{10,12}$.

\section{Materials and methods}

Animals and feed

The experimental procedures for the present trial were reviewed and approved by the Crown Research Institute Animal Ethics Committee (Palmerston North, New Zealand)

Abbreviations: AA, amino acid; BCAA, branched-chain amino acid; EAA, essential amino acid; ICG, indocyanine green; MDV, mesenteric-drained viscera; NEAA, non-essential amino acid; PAH, $\rho$-aminohippuric acid; PDV, portal-drained viscera; SAA, sulfur amino acid; TSP, total splanchnic tissue.

* Corresponding author: Dr Nicole Roy, fax +64 6351 8003, email nicole.roy@agresearch.co.nz 
according to the Animals Protection Act (1960) and Animals Protection Regulations (1987) and amendments.

Wether lambs $(33 \mathrm{~kg})$ were weaned from their dams and transported to AgResearch Grasslands (Palmerston North). The lambs were shorn, drenched twice with ivermectin (Ivomec ${ }^{\circledR}$ Merial; New Zealand Ltd, Manakau City, New Zealand) and treated for external parasites using Wipeout (Coopers; Schering-Plough Animal Health Ltd, Upper Hut, Wellington, New Zealand). The lambs were fed Lucerne pellets $(800 \mathrm{~g} \mathrm{DM} / \mathrm{d})$ and chaffed Lucerne hay $(200 \mathrm{~g} \mathrm{DM} / \mathrm{d})$ for approximately 3 weeks. The lambs were brought indoors 1 week before surgery, housed in individual metabolism crates and maintained on the same diet until $3 \mathrm{~d}$ after surgery.

Twelve lambs were fasted for $24 \mathrm{~h}$ before surgery as described previously ${ }^{10}$. Permanent indwelling catheters were placed in the mesenteric artery and the mesenteric, portal and hepatic veins ${ }^{13}$, vena cava and abdominal aorta ${ }^{14}$ for blood sampling and infusions of dyes and isotope-labelled AA to measure plasma flow and arterio-venous concentration differences of AA (unlabelled and labelled), metabolite or insulin. Additionally, a permanent Teflon cannula was fitted in the abomasum in preparation for the infusion of labelled AA to determine whole-body and tissue AA kinetics on day 48 post-infection ${ }^{10,12}$. The lambs received a daily intramuscular injection of procaine penicillin $(3 \mathrm{ml})$ for $4 \mathrm{~d}$ post-surgery. Catheters were maintained as described previously ${ }^{13}$.

When intake had recovered after surgery, the lambs were offered fresh Sulla (Hedysarum coronarium) at approximately $800 \mathrm{~g} \mathrm{DM} / \mathrm{d}$ until the conclusion of the trial ${ }^{10}$. The reason for selecting Sulla instead of the usual ryegrass-white clover dominant New Zealand pasture was in part to ensure that the lambs were fed forage of consistent quality ${ }^{10}$. The Sulla was harvested every $2 \mathrm{~d}$ with a sickle bar mower by 10.00 hours and stored at $4{ }^{\circ} \mathrm{C}$. The DM content of the Sulla was determined daily in order to adjust the amount of wet forage given to maintain DM offered at approximately $800 \mathrm{~g} / \mathrm{d}$. The intake of $800 \mathrm{~g} / \mathrm{d}$ was chosen to be below ad libitum intake (at about 0.6 to 0.8 of maintenance) to ensure that the control and parasitised animals ate similar amounts. The lambs were fed at hourly intervals from overhead feeders and water was available ad libitum. The lambs were weighed weekly to monitor live-weight changes during the experimental period.

\section{Treatment and parasitology}

At 1 week after surgery (day 1 of the experimental period), six sheep were given $6000 \mathrm{~T}$. colubriformis L3 larvae per d orally for $6 \mathrm{~d}$ (parasite treatment) while the remaining six sheep were drenched with ivermectin once to serve as controls (control treatment). This infection protocol was essentially a single dose, with the larval dose split across $6 \mathrm{~d}$ to reduce the possibility of rumen bypass and therefore maximise the establishment of larvae in the small intestine. The reasons for the choice of this method for larvae dosing have been fully described ${ }^{10}$. Briefly, due to the extensive surgical procedure that the lambs underwent, it was decided that, for ethical reasons, the lambs would not be exposed to the constant demands of a trickle infection.

The lambs were assigned to either the control or parasitised group according to a completely randomised block design. Due to the time-consuming nature of the surgical procedure, a maximum of four lambs were surgically modified in any week. For this reason, the lambs were blocked according to the week that they underwent surgery, referred to as the group effect in the statistical model.

Faecal egg counts from individual sheep were determined every second day from day 20 to day 45 of infection using the modified McMaster method in which one egg counted equates to fifty eggs/g wet faeces ${ }^{15}$. Total intestinal worm burdens in the proximal $10 \mathrm{~m}$ of the small intestine were determined after slaughter ${ }^{16}$.

\section{Infusions, blood sampling and analysis}

On day 48, p-aminohippuric acid (PAH; $723 \mathrm{mg} / \mathrm{h} ; 0.14 \mathrm{~mm}$; $\mathrm{Na}$ form, dissolved in water and then autoclaved) was infused into the mesenteric vein for $8 \mathrm{~h}$ to measure plasma flow across the intestinal and hepatic tissues. The lambs also received an infusion of indocyanine green (ICG) for $8 \mathrm{~h}$ into the abdominal aorta $(14.6 \mathrm{mg} / \mathrm{h} ; 0.83 \mathrm{mM}-\mathrm{ICG})$ to estimate plasma flow across the hindquarters ${ }^{17}$. The ICG was dissolved in deionised water and $1 \%$ albumin and $0.9 \% \mathrm{NaCl}$ were added to stabilise the ICG and ensure the solution was isotonic. The infusate was filter sterilised $(0 \cdot 2 \mu \mathrm{m})$ immediately before infusion. To prevent blood clotting during the continuous sampling, 2000 international units ovine heparin were infused per $\mathrm{h}$ into the jugular vein of the lambs over the $8 \mathrm{~h}$ infusion period ${ }^{5}$. Sampling lines and syringes were kept in an ice water-bath to minimise the degradation of blood constituents ${ }^{5}$. Blood was withdrawn continuously every $2 \mathrm{~h}$ from the mesenteric artery $(10 \mathrm{ml}$ for time 0 to $2 \mathrm{~h}$ and time 2 to $4 \mathrm{~h}$ for isotopic plateau; $30 \mathrm{ml}$ for time 4 to $6 \mathrm{~h}$ and time 6 to $8 \mathrm{~h}$ for isotopic plateau and net metabolite flux), the mesenteric, portal, and hepatic veins and the vena cava $(30 \mathrm{ml}$ for time 4 to $6 \mathrm{~h}$ and time 6 to $8 \mathrm{~h}$ for net metabolite flux only) over the infusion period. The blood removed from the mesenteric artery at all time points was used to establish the isotopic plateau for the infusion procedure used here. Plasma data presented in the present paper represent the average of samples taken from the last two sampling periods from the mesenteric, portal and hepatic veins, the vena cava and the mesenteric artery (times 4 to 6 and 6 to $8 \mathrm{~h}$ ). These times correspond to the isotopic plateau and were selected for the measurement of tissue AA fluxes (present paper) and kinetics ${ }^{10,12}$.

After each $2 \mathrm{~h}$ collection period, the syringes were removed from the collection lines and carefully mixed by gentle rotation. Packed cell volume was determined. Immediately following the collection of blood samples, approximately $0.2 \mathrm{ml}$ blood was introduced onto a blood gas analyser (ABL3; Radiometer Pacific Limited, Copenhagen, Denmark) to determine oxygen, carbon dioxide, glucose and lactate concentrations. The remaining whole blood was centrifuged $\left(4^{\circ} \mathrm{C}\right.$; $3270 \mathrm{~g}$ for $15 \mathrm{~min}$ ), the plasma harvested and either processed immediately or stored at $-85^{\circ} \mathrm{C}$ for further analysis as described previously ${ }^{10}$.

To determine the concentration of AA, $0.5 \mathrm{ml}$ plasma was treated with $25 \mu 180 \mathrm{~mm}$-dithiothreitol (in $0 \cdot 1 \mathrm{M}$-phosphate buffer (pH 8.0) as an antioxidant for all AA) and $15 \mu l 3$ mM-norleucine (an internal standard with phenol $(1 \mathrm{~g} / \mathrm{l})$ as a preservative) and stored at $-85^{\circ} \mathrm{C}$ until processed as described previously $^{10}$. Plasma AA concentrations were determined by reverse-phase HPLC separation of phenylisothiocyanate 
derivatives, using a Waters Pico-Tag ${ }^{\circledR}$ column $(3.9 \times 300 \mathrm{~mm}$; Waters Corporation, Milford, MA, USA) modified from Bidlingmeyer et al. ${ }^{18}$ on a Shimadzu 10A HPLC system (Shimadzu Scientific Instruments Ltd, Columbia, MD, USA).

To determine plasma cysteine concentrations, plasma ( $2 \mathrm{ml})$ was mixed with $1 \mathrm{ml}$ of a solution containing SDS (7.5 g/l) and $9 \mathrm{~mm}$-EDTA and $200 \mu \mathrm{l}$ dithiothreitol $(80 \mathrm{~mm}$ in $0.1 \mathrm{M}$-phosphate buffer, $\mathrm{pH} 8.0)$ added. Norleucine $(100 \mu \mathrm{l} ; 3 \mathrm{~mm}$ in phenol $(1 \mathrm{~g} / \mathrm{l}))$ was added as an internal standard. The samples were weighed after each addition and left at room temperature for $15 \mathrm{~min}$ before the addition of $1 \mathrm{ml} \mathrm{TCA}(300 \mathrm{~g} / \mathrm{kg})$ to precipitate plasma proteins. The tubes were centrifuged $(3270 \mathrm{~g}$ for $15 \mathrm{~min}$ at $4{ }^{\circ} \mathrm{C}$ ) and the supernatant fraction filtered $\left(0.45 \mu \mathrm{m}\right.$; cellulose acetate) and stored at $-85^{\circ} \mathrm{C}$. The plasma cysteine concentration was measured at $570 \mathrm{~nm}$ using a continuous flow analyser (Technicon Autoanalyser II; Technicon Corporation, Ardsley, NY, USA $)^{19}$.

To determine ammonia concentrations, $1.5 \mathrm{ml}$ plasma was mixed with $0.5 \mathrm{ml} \mathrm{TCA}(300 \mathrm{~g} / \mathrm{kg})$ and centrifuged $(3270 \mathrm{~g}$ for $15 \mathrm{~min}$ at $4{ }^{\circ} \mathrm{C}$ ) on the day of sampling. The supernatant fraction was filtered and stored at $-85^{\circ} \mathrm{C}$ until it was injected onto a Tecator FIAstar Flow Injection 5010 Analyser (Tecaort Ltd, Höganäs, Sweden) and the absorbance at $590 \mathrm{~nm}$ wavelength measured.

Urea concentrations in plasma were determined using a commercial assay kit (catalogue number 073685 6; Roche Diagnostics Ltd, Basel, Switzerland). The urea concentrations were corrected for background plasma ammonia determined using a second assay (catalogue number 171C; Sigma Diagnostics Ltd, St Louis, MO, USA). The urea and ammonia assays were performed on a Cobas Fara II analyser (Hoffmann La Roche, Basel, Switzerland).

Plasma insulin concentrations were measured in portal, hepatic and arterial plasma samples using a double antibody RIA $^{20}$. Intra- and inter-assay CV were 8.7 and $12.9 \%$ respectively. The mean sensitivity was $22.7 \mathrm{pg}$ insulin $/ \mathrm{ml}$.

PAH dye dilution was used to determine the flow of plasma through the PDV, liver and TSP tissues as described previously $^{21}$ with an additional deacylation step ${ }^{5}$. Samples and standards were read at $540 \mathrm{~nm}$ using a spectrophotometer (GBC UV/VIS 918; GBC Scientific Equipment Pty Ltd, Dandenong, Vic, Australia).

Plasma flow across the hindquarters was calculated using ICG dye dilution. Plasma $(1 \mathrm{ml})$ was thawed and centrifuged at $3270 \mathrm{~g}$ for $15 \mathrm{~min}$ at $4{ }^{\circ} \mathrm{C}$ and the absorbance at $790 \mathrm{~nm}$ measured in a spectrophotometer (GBC UV/VIS 918; GBC Scientific Equipment Pty Ltd ${ }^{17}$.

\section{Calculations}

Plasma flow across the MDV, PDV, liver and TSP were determined by equation 1 :

Tissue plasma flow $(\mathrm{ml} / \mathrm{min})$

$$
=\frac{[\mathrm{PAH}]_{\mathrm{I}}(\mathrm{mg} / \mathrm{ml}) \times \text { infusion rate }(\mathrm{ml} / \mathrm{min})}{\left([\mathrm{PAH}]_{\mathrm{X}}-[\mathrm{PAH}]_{\mathrm{A}}\right)(\mathrm{mg} / \mathrm{ml})},
$$

where subscripts I, $\mathrm{X}$ or A refer to the concentration of PAH in the infusate, venous drainage of the tissue bed or mesenteric artery, respectively. Plasma flow in the hepatic artery was calculated as the difference between the plasma flow across the TSP and the PDV. Plasma flow across the hindquarters was determined by replacing the concentration of $\mathrm{PAH}$ in equation 1 with that of ICG.

The net fluxes of each nutrient and individual AA, metabolite or insulin across the MDV, PDV and TSP and hindquarters were calculated using equation 2 :

$$
\begin{aligned}
& \text { Tissue net flux }(\mathrm{mmol} / \mathrm{min}) \\
& =\text { (concentration of } \mathrm{Z}_{\mathrm{A}} \\
& \left.\quad-\text { concentration of } \mathrm{Z}_{\mathrm{X}}\right)(\mathrm{mmol} / \mathrm{ml}) \\
& \quad \times \text { tissue plasma flow }(\mathrm{ml} / \mathrm{min}),
\end{aligned}
$$

where $\mathrm{A}$ is the concentration in the mesenteric artery, $\mathrm{X}$ is the concentration in the venous drainage and $\mathrm{Z}$ is the nutrient in question (for example, glucose, valine etc). Additionally, in order to quantify the partitioning of AA across the visceral tissues, the difference between the net flux in the PDV and MDV was calculated. AA were grouped as non-essential AA (NEAA; alanine, aspartate, glutamate, glycine, proline, serine and tyrosine), essential AA (EAA; arginine, cysteine, histidine, isoleucine, leucine, lysine, methionine, phenylalanine, threonine and valine), branched-chain AA (BCAA; isoleucine, leucine and valine), sulfur AA (SAA; cysteine and methionine) and total AA (NEAA and EAA). Positive values represent a net uptake by the tissue, while a negative value represents a net release. Results are presented as leastsquares means and associated pooled standard deviation. Where the results are presented in the text, the following format is used: control values $v$. parasitised values.

Similarly, the net flux of each individual AA, metabolite or insulin across the liver was calculated using equation 3 :

Net flux of nutrient across the liver $(\mathrm{mmol} / \mathrm{min})$

$$
\begin{aligned}
= & \left(\text { concentration of } \mathrm{Z}_{\mathrm{A}}(\mathrm{mmol} / \mathrm{ml})\right. \\
& \times \text { hepatic artery plasma flow }(\mathrm{ml} / \mathrm{min}) \\
& +\left(\text { concentration of } \mathrm{Z}_{\mathrm{P}}(\mathrm{mmol} / \mathrm{ml})\right. \\
& \times \text { PDV plasma flow }(\mathrm{ml} / \mathrm{min})) \\
& -\left(\text { concentration of } \mathrm{Z}_{\mathrm{H}}(\mathrm{mmol} / \mathrm{ml})\right. \\
& \times \text { TSP plasma flow }(\mathrm{ml} / \mathrm{min}))
\end{aligned}
$$

where $\mathrm{A}$ is the concentration in the mesenteric artery, $\mathrm{P}$ is the concentration in the portal vein, $\mathrm{H}$ is the concentration in the hepatic vein and $\mathrm{Z}$ is the nutrient in question (for example, glucose, valine etc).

\section{Statistical analysis}

Statistical analysis for all variables was performed using a general linear model (SAS Software version 8, 1999-2001; SAS Institute Inc., Cary, NC, USA), with treatment and group (the week that the lamb underwent surgery) used as sources of variation in the model. Additionally, feed intake, 
faecal egg counts and live weight were analysed using 'Proc Mix' repeated measures. The data were checked for normality and the presence of outliers by plotting residuals $v$. the predicted residuals. Faecal egg counts were transformed by $\ln$ $(x+1)$ before analysis in order to ensure symmetry in the data and to standardise variances across the treatments ${ }^{22}$.

Statistical difference from zero for arterio-venous concentration differences of oxygen, carbon dioxide, glucose, lactate, ammonia, urea, insulin and AA was determined using the $t$ statistic, with a probability greater than 0.05 considered as non-significant. All arterio-venous values (data not presented) were statistically different from zero.

Probabilities for concentration, net flux and inflow and outflow of AA, metabolite or hormone (data not listed here) lower than 0.05 were considered to indicate a significant difference between control and parasitised lambs and values between 0.05 and 0.10 to indicate a trend.

\section{Results}

Feed intake, live weight and parasitology

Results relating to feed intake, live weight and parasitology have already been presented ${ }^{10}$. Briefly, the significant parasite burden (240 v. 18000 (SD 7000) adult worms; $P<0.001$ ) caused by the presence of $T$. colubriformis in the small intestine had no effect on feed intake (769 v. 689 (SD 47) g DM/d; $P=0 \cdot 12)$. However, live-weight gain tended to be reduced over the last $20 \mathrm{~d}$ of the infection period $(50 v$. -50 (SD 70) $\mathrm{g} / \mathrm{d} ; P=0 \cdot 06)$.

\section{Nutrient concentrations}

Plasma concentrations of AA in the mesenteric vein were not affected by parasite infection, with the exception of histidine, which decreased in the infected lambs $(P<0 \cdot 05)$ (Table 1). The combined plasma concentrations of total AA, NEAA, EAA, BCAA and SAA in the mesenteric vein were also unaffected $(P>0.10$; total AA, 2600 v. 2495 (SD 486) $\mu \mathrm{M}$; NEAA,

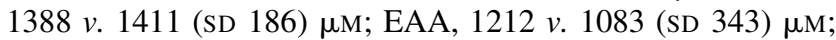
BCAA, $579 v .538$ (SD 178) $\mu \mathrm{M}$; SAA, $73 v .56$ (SD 15) $\mu \mathrm{M}$ ).

In the portal vein, plasma concentrations of alanine and histidine were decreased in the infected lambs $(P<0.05$; Table 1$)$ and plasma glycine concentration tended to increase in the same animals $(P<0 \cdot 10)$. The remaining plasma AA concentrations were similar between treatments $(P<0 \cdot 05)$ and there was no effect on the plasma concentrations of total AA (1927 v. 2074 (SD 302) MM), NEAA (1062 v. 1229 (SD 154) $\mu \mathrm{M})$, EAA (881 v. 845 (SD 211) $\mu \mathrm{M})$, BCAA (439 v. 435 $(\mathrm{SD} 104) \mu \mathrm{M})$ or SAA $(53 v .44(\mathrm{SD} 9) \mu \mathrm{M})$ in the portal vein (Table 1).

The plasma concentrations of AA followed similar trends in the hepatic vein, with only alanine and histidine being reduced in parasitised lambs. In contrast, the concentration of glycine in the hepatic vein was increased by an established parasitic infection (Table 1). The plasma concentrations of NEAA tended to increase in the hepatic vein of parasitised lambs (1005 v. 1172 (SD 145) $\mu \mathrm{M} ; P<0 \cdot 10$ ). There was, however, no effect of infection on total AA, EAA, BCAA or SAA $(P>0 \cdot 10$; total AA, $1747 v .1985$ (SD 310) $\mu \mathrm{M}$; EAA, $762 v$.
759 (SD 230) $\mu \mathrm{M}$; BCAA, 389 v. 420 (SD 123) $\mu \mathrm{M}$; SAA 50 v. $41(\mathrm{SD} 8) \mu \mathrm{M})$.

In the mesenteric artery, plasma aspartic acid, glycine $(P<0.05)$ and serine $(P<0 \cdot 10)$ were increased in the infected lambs (Table 1). The plasma concentrations of NEAA were increased in the mesenteric artery of parasitised lambs (991 v. 1215 (SD 158) $\mu \mathrm{M} ; P<0 \cdot 05$ ). No effect of infection was observed on total AA, EAA, BCAA or SAA concentration in the mesentery artery of both control and infected lambs $(P>0 \cdot 10$; total AA, 1688 v. 2047 (SD 318) $\mu \mathrm{M}$; EAA, $718 v$. 772 (SD 224) $\mu \mathrm{M}$; BCAA, 354 v. 414 (SD 116) $\mu \mathrm{M}$; SAA, 48 v. 42 (SD 9) $\mu \mathrm{M})$.

In the vena cava, plasma concentrations of glycine and serine were increased with infection $(P<0.05)$ while the concentration of cysteine in plasma tended to decrease in the infected lambs $(P<0 \cdot 10)$ (Table 1$)$. The plasma concentrations of NEAA tended to increase $(P<0 \cdot 10)$ in the vena cava of parasitised lambs (1001 v. 1239 (SD 183) $\mu \mathrm{M}$; $P<0 \cdot 10)$. However, there was no effect of infection on total AA, EAA, BCAA or SAA concentration in the vena cava of both control and infected lambs $(P>0 \cdot 10$; total AA, $1715 v$. 2048 (SD 300) $\mu \mathrm{M}$; EAA, 714 v. 809 (SD 200) $\mu \mathrm{M}$; BCAA, 341 v. 410 (SD 109) $\mu \mathrm{M}$; SAA, 49 v. 43 (SD 9) $\mu \mathrm{M}$ ).

The concentrations of oxygen, carbon dioxide, ammonia and urea in all vessels were not affected $(P>0 \cdot 10)$ by parasitic infection (Table 1). Glucose concentrations were lower in the mesenteric $(P<0 \cdot 10)$ and portal veins $(P<0 \cdot 05)$ and the mesenteric artery $(P<0 \cdot 05)$ of the infected lambs. Lactate concentrations were lower $(P<0.05)$ in the portal vein and tended to be lower $(P<0 \cdot 10)$ in the hepatic vein, the mesenteric artery and vena cava of parasitised lambs. Plasma insulin concentrations were similar in the mesenteric artery and hepatic vein, but were lower $(P<0 \cdot 05)$ in the portal vein of parasitised lambs.

\section{Plasma flow and net nutrient fluxes}

Plasma flow across the MDV was similar $(P>0 \cdot 10)$ between control and infected lambs (Table 2). All AA were released across the MDV, with the exception of glutamine which was taken up by the MDV (Table 2). Net fluxes of total AA, NEAA, EAA, BCAA and SAA across the MDV were similar $(P>0 \cdot 10)$ between the control and parasitised lambs.

Despite similar AA fluxes across the MDV, parasitic infection resulted in a $28 \%$ reduction $(P<0.05)$ in the flux of total AA released from the PDV. Most AA were released by the PDV (Table 2); however, parasitic infection reduced $(P<0.05)$ the release of NEAA, EAA, BCAA and SAA from this tissue bed (Table 2). The utilisation of glutamine by the PDV of the control lambs was twice that in the infected lambs $(P<0.05)$. Hydroxyproline was taken up by the PDV of control lambs but released by the PDV in the infected lambs $(P<0 \cdot 10)$. Threonine, in contrast, was released by the PDV of control lambs and taken up by the PDV of the parasitised lambs $(P<0.05)$. Aspartic acid, glutamic acid, glycine, cysteine, lysine and tyrosine releases across the PDV were similar between treatments $(P>0 \cdot 10$; Table 2$)$. There was no effect of parasitic infection on the partitioning of AA in the visceral tissues, as indicated by the difference between PDV and MDV plasma AA fluxes ( $P>0.05$; Table 2). 
Table 1. Concentrations of amino acids $(\mu \mathrm{mol} / \mathrm{l})$, ammonia $(\mu \mathrm{mol} / \mathrm{l})$ and urea $(\mathrm{mmol} / \mathrm{l})$ in plasma, carbon dioxide, oxygen, glucose and lactate in blood $(\mathrm{mmol} / \mathrm{l})$ and insulin in plasma $(\mathrm{ng} / \mathrm{ml})$ in lambs fed fresh Sulla (Hedysarum coronarium) without (control) or with Trichostrongylus colubriformis infection (parasite)

(Least-squares means and associated pooled standard deviations)

\begin{tabular}{|c|c|c|c|c|c|c|c|c|c|c|c|c|c|c|c|c|c|c|c|c|}
\hline & \multicolumn{4}{|c|}{ Mesenteric vein } & \multicolumn{4}{|c|}{ Portal vein } & \multicolumn{4}{|c|}{ Hepatic vein } & \multicolumn{4}{|c|}{ Mesenteric artery } & \multicolumn{4}{|c|}{ Vena cava } \\
\hline & $\begin{array}{c}\text { Control } \\
(n 6)\end{array}$ & $\begin{array}{l}\text { Parasite } \\
(n 6)\end{array}$ & SD & $P$ & $\begin{array}{l}\text { Control } \\
(n 6)\end{array}$ & $\begin{array}{l}\text { Parasite } \\
(n 6)\end{array}$ & SD & $P$ & $\begin{array}{l}\text { Control } \\
(n 6)\end{array}$ & $\begin{array}{l}\text { Parasite } \\
(n 6)\end{array}$ & SD & $P$ & $\begin{array}{c}\text { Control } \\
(n 6)\end{array}$ & $\begin{array}{l}\text { Parasite } \\
(n 6)\end{array}$ & SD & $P$ & $\begin{array}{c}\text { Control } \\
(n 6)\end{array}$ & $\begin{array}{l}\text { Parasite } \\
(n 6)\end{array}$ & SD & $P$ \\
\hline \multicolumn{21}{|c|}{ Non-essential amino acids } \\
\hline Alanine & 257 & 206 & 44 & 0.11 & 177 & 143 & 18 & 0.02 & 144 & 123 & 16 & 0.04 & 142 & 128 & 18 & 0.23 & 165 & 150 & 17 & 0.21 \\
\hline Asparagine & 92 & 76 & 29 & 0.42 & 51 & 45 & 11 & 0.35 & 41 & 38 & 11 & 0.66 & 38 & 39 & 10 & 0.86 & 36 & 38 & 9 & 0.75 \\
\hline Aspartic acid & 19 & 22 & 11 & 0.66 & 12 & 15 & 5 & 0.22 & 10 & 14 & 5 & 0.19 & 8 & 12 & 3 & 0.06 & 9 & 10 & 4 & 0.53 \\
\hline Glutamine & 271 & 249 & 28 & 0.25 & 256 & 254 & 27 & 0.88 & 263 & 259 & 40 & 0.84 & 283 & 292 & 40 & 0.71 & 319 & 317 & 45 & 0.93 \\
\hline Glutamic acid & 97 & 105 & 39 & 0.76 & 75 & 87 & 25 & 0.46 & 86 & 94 & 24 & 0.57 & 67 & 79 & 17 & 0.27 & 57 & 61 & 18 & 0.75 \\
\hline Glycine & 403 & 493 & 106 & 0.21 & 323 & 501 & 135 & 0.07 & 315 & 471 & 127 & 0.06 & 315 & 490 & 138 & 0.06 & 292 & 492 & 125 & 0.04 \\
\hline Hydroxyproline & 19 & 23 & 8 & 0.45 & 20 & 21 & 8 & 0.79 & 18 & 21 & 7 & 0.54 & 19 & 21 & 8 & 0.73 & 20 & 21 & 9 & 0.83 \\
\hline Proline & 135 & 131 & 37 & 0.89 & 93 & 94 & 17 & 0.94 & 82 & 86 & 16 & 0.65 & 77 & 88 & 17 & 0.28 & 79 & 88 & 14 & 0.33 \\
\hline Serine & 96 & 107 & 22 & 0.46 & 56 & 72 & 22 & 0.28 & 46 & 68 & 21 & 0.11 & 43 & 67 & 18 & 0.05 & 37 & 63 & 18 & 0.05 \\
\hline \multicolumn{21}{|c|}{ Essential amino acid } \\
\hline Arginine & 126 & 110 & 33 & 0.46 & 104 & 90 & 22 & 0.31 & 93 & 83 & 22 & 0.46 & 91 & 86 & 21 & 0.73 & 96 & 91 & 19 & 0.71 \\
\hline Cysteine & 37 & 30 & 6 & 0.10 & 31 & 28 & 6 & 0.37 & 32 & 26 & 6 & 0.12 & 31 & 26 & 6 & 0.20 & 33 & 26 & 6 & 0.09 \\
\hline Histidine & 67 & 47 & 12 & 0.03 & 55 & 38 & 8 & 0.01 & 48 & 36 & 8 & 0.04 & 47 & 38 & 9 & 0.10 & 47 & 39 & 10 & 0.26 \\
\hline Isoleucine & 124 & 107 & 48 & 0.58 & 85 & 77 & 24 & 0.58 & 72 & 73 & 28 & 0.95 & 64 & 72 & 26 & 0.60 & 59 & 71 & 22 & 0.41 \\
\hline Leucine & 166 & 151 & 49 & 0.63 & 112 & 115 & 27 & 0.89 & 99 & 109 & 30 & 0.56 & 87 & 108 & 28 & 0.24 & 82 & 107 & 26 & 0.17 \\
\hline Lysine & 106 & 109 & 44 & 0.92 & 72 & 92 & 34 & 0.35 & 63 & 86 & 31 & 0.23 & 57 & 87 & 29 & 0.11 & 62 & 84 & 27 & 0.22 \\
\hline Methionine & 36 & 26 & 12 & 0.25 & 22 & 17 & 5 & 0.16 & 17 & 15 & 5 & 0.46 & 16 & 16 & 5 & 0.99 & 17 & 17 & 6 & 0.84 \\
\hline Phenylalanine & 72 & 61 & 20 & 0.38 & 50 & 42 & 11 & 0.24 & 39 & 35 & 11 & 0.59 & 37 & 37 & 10 & 0.91 & 38 & 39 & 8 & 0.84 \\
\hline Threonine & 102 & 86 & 34 & 0.46 & 61 & 53 & 17 & 0.49 & 51 & 53 & 19 & 0.83 & 48 & 54 & 18 & 0.61 & 48 & 56 & 15 & 0.46 \\
\hline Tyrosine & 87 & 77 & 25 & 0.51 & 63 & 51 & 16 & 0.24 & 51 & 45 & 17 & 0.54 & 49 & 47 & 16 & 0.80 & 50 & 49 & 14 & 0.94 \\
\hline Valine & 289 & 280 & 83 & 0.87 & 241 & 243 & 56 & 0.95 & 217 & 237 & 67 & 0.62 & 203 & 235 & 64 & 0.41 & 200 & 232 & 63 & 0.43 \\
\hline \multicolumn{21}{|c|}{ Metabolites and insulin } \\
\hline Oxygen & 3.27 & 3.23 & 0.38 & 0.88 & 3.83 & 3.80 & 0.37 & 0.91 & 2.93 & $3 \cdot 10$ & 0.33 & 0.42 & 4.74 & 4.83 & 0.75 & 0.85 & $2 \cdot 67$ & 2.69 & 0.25 & 0.89 \\
\hline Carbon dioxide & 26.60 & 26.37 & 1.12 & 0.76 & 26.32 & 26.50 & 0.92 & 0.76 & 26.73 & $26 \cdot 70$ & 1.03 & 0.96 & $25 \cdot 70$ & 25.49 & 0.90 & 0.70 & 27.04 & 26.97 & 0.99 & 0.90 \\
\hline Glucose & 3.84 & 3.53 & 0.25 & 0.09 & 3.81 & 3.41 & 0.18 & 0.01 & 3.88 & 3.64 & 0.28 & 0.22 & 3.84 & 3.50 & 0.24 & 0.04 & 3.61 & 3.46 & 0.20 & 0.25 \\
\hline Lactate & 0.80 & 0.68 & 0.19 & 0.35 & 0.97 & 0.68 & 0.18 & 0.03 & 0.87 & 0.54 & 0.26 & 0.08 & 0.78 & 0.55 & 0.20 & 0.08 & 0.83 & 0.59 & 0.21 & 0.10 \\
\hline Ammonia & 0.68 & 0.76 & 0.20 & 0.56 & 0.88 & 0.86 & 0.23 & 0.90 & 0.23 & 0.23 & 0.05 & 0.95 & 0.20 & 0.21 & 0.03 & 0.56 & 0.20 & 0.20 & 0.03 & 0.86 \\
\hline Urea & 5.70 & 5.50 & 1.61 & 0.85 & 5.09 & 5.42 & 1.41 & 0.71 & $6 \cdot 14$ & 5.54 & 1.43 & 0.52 & 5.69 & 5.40 & 1.50 & 0.75 & 5.92 & $5 \cdot 37$ & 1.32 & 0.52 \\
\hline Insulin & ND & ND & ND & ND & 1.59 & 0.63 & 0.48 & 0.01 & 1.36 & 0.70 & 0.62 & 0.11 & 1.11 & 0.59 & 0.58 & 0.16 & ND & ND & ND & ND \\
\hline
\end{tabular}

ND, not determined. 
Table 2. Plasma flow ( $\mathrm{ml} / \mathrm{min}$ ) and net flux ( $\mu \mathrm{mol} / \mathrm{min}$ ) of amino acids across the mesenteric-drained viscera (MDV) and portal-drained viscera (PDV) in lambs fed fresh Sulla (Hedysarum coronarium) without (control) or with Trichostrongylus colubriformis infection (parasite) ${ }^{\star}$

(Least-squares means and associated pooled standard deviations)

\begin{tabular}{|c|c|c|c|c|c|c|c|c|c|c|c|c|}
\hline & \multicolumn{4}{|c|}{ MDV } & \multicolumn{4}{|c|}{ PDV } & \multicolumn{4}{|c|}{ MDV - PDV } \\
\hline & $\begin{array}{c}\text { Control } \\
(n 6)\end{array}$ & $\begin{array}{c}\text { Parasite } \\
(n 6)\end{array}$ & SD & $P$ & $\begin{array}{c}\text { Control } \\
(n 6)\end{array}$ & $\begin{array}{c}\text { Parasite } \\
\quad(n 6)\end{array}$ & SD & $P$ & $\begin{array}{c}\text { Control } \\
(n 6)\end{array}$ & $\begin{array}{c}\text { Parasite } \\
\quad(n 6)\end{array}$ & SD & $P$ \\
\hline Plasma flow & 553 & 663 & 280 & 0.51 & 1518 & 1398 & 369 & 0.61 & & & & \\
\hline \multicolumn{13}{|l|}{ Non-essential amino acids } \\
\hline Alanine & $-61 \cdot 7$ & $-55 \cdot 2$ & $44 \cdot 0$ & 0.83 & $-47 \cdot 6$ & $-22 \cdot 0$ & $16 \cdot 6$ & 0.03 & 24.9 & $30 \cdot 1$ & $33 \cdot 8$ & 0.83 \\
\hline Asparagine & $-28 \cdot 9$ & $-26 \cdot 9$ & $21 \cdot 1$ & 0.89 & $-16 \cdot 7$ & -8.6 & $5 \cdot 8$ & 0.06 & $18 \cdot 3$ & $16 \cdot 6$ & $16 \cdot 7$ & 0.89 \\
\hline Aspartic acid & -5.4 & $-7 \cdot 3$ & 4.4 & 0.54 & $-4 \cdot 3$ & -3.9 & $3 \cdot 2$ & 0.86 & $3 \cdot 2$ & $2 \cdot 2$ & $3 \cdot 1$ & 0.67 \\
\hline Glutamine & $9 \cdot 6$ & $29 \cdot 6$ & $18 \cdot 1$ & 0.14 & $26 \cdot 9$ & $55 \cdot 1$ & $16 \cdot 6$ & 0.02 & 23.9 & $27 \cdot 1$ & $12 \cdot 4$ & 0.18 \\
\hline Glutamic acid & $-17 \cdot 7$ & -22.9 & $8 \cdot 2$ & 0.37 & -7.7 & $-11 \cdot 6$ & $16 \cdot 6$ & 0.72 & $11 \cdot 7$ & $1 \cdot 3$ & $17 \cdot 2$ & 0.41 \\
\hline Glycine & -45.9 & -41.5 & $27 \cdot 6$ & 0.82 & $-39 \cdot 4$ & $-17 \cdot 0$ & 22.9 & $0 \cdot 16$ & $11 \cdot 6$ & $13 \cdot 2$ & $21 \cdot 7$ & 0.92 \\
\hline Hydroxyproline & -0.2 & -0.4 & 0.5 & 0.66 & 0.3 & -1.0 & $1 \cdot 0$ & 0.07 & 0.5 & -0.7 & 0.9 & 0.13 \\
\hline Proline & $-30 \cdot 7$ & $-27 \cdot 7$ & $19 \cdot 4$ & 0.83 & $-19 \cdot 2$ & -10.9 & $5 \cdot 8$ & 0.05 & $17 \cdot 4$ & $14 \cdot 7$ & $12 \cdot 2$ & 0.76 \\
\hline Serine & $-28 \cdot 6$ & $-26 \cdot 7$ & $16 \cdot 8$ & 0.87 & $-15 \cdot 6$ & $-6 \cdot 1$ & 5.5 & 0.03 & $17 \cdot 7$ & $23 \cdot 2$ & $17 \cdot 0$ & 0.65 \\
\hline \multicolumn{13}{|l|}{ Essential amino acids } \\
\hline Arginine & $-19 \cdot 6$ & $-16 \cdot 6$ & $15 \cdot 6$ & 0.78 & $-11 \cdot 3$ & $-2 \cdot 1$ & $6 \cdot 6$ & 0.06 & $12 \cdot 2$ & $15 \cdot 0$ & $9 \cdot 7$ & 0.69 \\
\hline Histidine & $-11 \cdot 2$ & $-9 \cdot 1$ & $8 \cdot 3$ & 0.71 & -9.0 & $-1 \cdot 1$ & 3.5 & 0.01 & $4 \cdot 1$ & $7 \cdot 9$ & $4 \cdot 7$ & 0.29 \\
\hline Isoleucine & $-32 \cdot 1$ & $-27 \cdot 2$ & $23 \cdot 3$ & 0.76 & -19.7 & $-7 \cdot 2$ & $7 \cdot 7$ & 0.03 & $19 \cdot 6$ & $17 \cdot 5$ & $17 \cdot 4$ & 0.87 \\
\hline Leucine & -42.9 & -35.5 & $31 \cdot 0$ & 0.73 & $-27 \cdot 0$ & -10.7 & $10 \cdot 4$ & 0.04 & $24 \cdot 0$ & $20 \cdot 8$ & $25 \cdot 2$ & 0.86 \\
\hline Lysine & $-27 \cdot 7$ & -23.9 & 21.5 & 0.80 & $-17 \cdot 8$ & $-9 \cdot 1$ & $10 \cdot 4$ & 0.22 & $14 \cdot 8$ & $10 \cdot 9$ & $14 \cdot 0$ & 0.70 \\
\hline Methionine & -10.5 & -8.5 & $8 \cdot 1$ & 0.72 & $-7 \cdot 1$ & $-1 \cdot 3$ & 2.9 & 0.01 & $5 \cdot 8$ & $6 \cdot 0$ & $6 \cdot 2$ & 0.97 \\
\hline Phenylalanine & $-19 \cdot 2$ & $-16 \cdot 4$ & $14 \cdot 3$ & 0.78 & -14.9 & -7.4 & $5 \cdot 7$ & 0.07 & 7.9 & $7 \cdot 1$ & 11.5 & 0.92 \\
\hline Threonine & $-31 \cdot 0$ & $-10 \cdot 3$ & 14.4 & 0.15 & -15.6 & 3.4 & $4 \cdot 3$ & 0.001 & 19.9 & $20 \cdot 2$ & $9 \cdot 0$ & 0.98 \\
\hline Tyrosine & $-21 \cdot 0$ & $-18 \cdot 1$ & $14 \cdot 2$ & 0.77 & $-12 \cdot 3$ & $-5 \cdot 8$ & $6 \cdot 3$ & 0.14 & $12 \cdot 1$ & $10 \cdot 4$ & $11 \cdot 7$ & 0.83 \\
\hline Valine & $-47 \cdot 7$ & $-37 \cdot 2$ & 32.5 & 0.64 & $-26 \cdot 3$ & -11.5 & $12 \cdot 8$ & $0 \cdot 10$ & $29 \cdot 3$ & $24 \cdot 9$ & $23 \cdot 2$ & 0.79 \\
\hline Non-essential amino acids & $-209 \cdot 5$ & $-179 \cdot 0$ & $143 \cdot 6$ & 0.76 & $-123 \cdot 3$ & $-26 \cdot 0$ & $47 \cdot 6$ & 0.01 & $129 \cdot 1$ & $137 \cdot 7$ & $107 \cdot 4$ & 0.91 \\
\hline Essential amino acid & $-302 \cdot 3$ & $-205 \cdot 5$ & $135 \cdot 2$ & 0.11 & $-163 \cdot 3$ & $-44 \cdot 1$ & $65 \cdot 8$ & 0.04 & $163 \cdot 2$ & $39 \cdot 6$ & $69 \cdot 0$ & 0.12 \\
\hline Branched-chain amino acids & $-122 \cdot 7$ & $-99 \cdot 9$ & $86 \cdot 2$ & 0.70 & $-72 \cdot 9$ & $-29 \cdot 4$ & $28 \cdot 2$ & 0.04 & $72 \cdot 8$ & 63.2 & $65 \cdot 5$ & 0.84 \\
\hline Sulfur amino acids & $-13 \cdot 7$ & $-11 \cdot 8$ & $9 \cdot 5$ & 0.77 & $-9 \cdot 4$ & $-3 \cdot 2$ & $3 \cdot 1$ & 0.01 & $7 \cdot 3$ & $8 \cdot 0$ & $7 \cdot 9$ & 0.90 \\
\hline Total amino acids & $-539 \cdot 1$ & -384.5 & $234 \cdot 1$ & 0.11 & $-291 \cdot 8$ & $-61 \cdot 1$ & $113 \cdot 1$ & 0.03 & 294.5 & $77 \cdot 8$ & $115 \cdot 4$ & 0.11 \\
\hline
\end{tabular}

*Positive values represent a net uptake by the tissue, while a negative value represents a net release.

Across the liver, parasitic infection decreased $(P<0 \cdot 05)$ the uptake of histidine and valine and resulted in a net release of threonine $(P<0.05$; Table 3$)$. The hepatic uptake of total AA, NEAA, EAA and SAA were similar $(P>0 \cdot 10)$ between the control and parasitised lambs, while there tended $(P<0 \cdot 10)$ to be a net utilisation of BCAA in the liver of parasitised lambs (Table 3).

Net fluxes of AA across the TSP are presented in Table 4. Total AA, EAA, SAA and NEAA were utilised by the TSP of infected animals $(P<0 \cdot 10)$ compared with a net release in the control lambs. Of the NEAA, asparagine and proline were affected by parasitic infection, with uptake of these AA by the TSP of infected lambs compared with their release in control lambs $(P<0 \cdot 05$; Table 4). Parasitic infection had a greater effect on the flux of EAA across the TSP, with only valine being similar between treatments $(P>0 \cdot 10)$. BCAA were released from the TSP of both control and parasitised lambs; however, infection decreased the release of this AA group $(P<0.05)$.

Despite the increased utilisation of AA by the TSP tissues of infected lambs, the presence of $T$. colubriformis in the small intestine had no effect on the net flux of AA across the hindquarters $(P>0 \cdot 10)$ with the exception of aspartic acid, which was utilised in the parasitised lambs but released in the control lambs (Table 5). Overall, there was a release of total AA and NEAA from the hindquarters of both the control and parasitised lambs and these fluxes were similar between treatments $(P>0 \cdot 10)$. EAA were utilised similarly by the hindquarters of the control and parasitised lambs.

The net fluxes of oxygen, carbon dioxide, ammonia and urea across the MDV, PDV, liver, TSP and hindquarters were unaffected by the presence of an established adult population of $T$. colubriformis in the small intestine (Table 6). Lactate was utilised by the liver $(P<0 \cdot 10)$ in parasitised lambs, whilst it was released in control lambs. Similar trends for lactate release were observed in the TSP $(P<0 \cdot 10)$. Infection decreased the utilisation of glucose by the hindquarters $(P<0.05)$. The net release of insulin across the PDV was also lower $(P<0 \cdot 05)$ in parasitised lambs; however, net fluxes across the liver and TSP were similar between treatments $(P>0 \cdot 10)$.

\section{Discussion}

The present study reports new insights on the effects of an established parasitic infection on AA metabolism across the TSP and hindquarter tissue beds in lambs fed fresh forage. Despite similar feed intake ${ }^{10}$, intestinal AA digestibility ${ }^{12}$ and net appearance of AA in the MDV drainage, the presence of an adult parasite burden in the small intestine decreased the release of AA by the PDV by $28 \%$. This reduction in appearance of the majority of AA in the portal drainage is in agreement with the results observed by Yu et $a l .{ }^{4}$ who noted a $24 \%$ increase in leucine sequestration by the PDV and a $30 \%$ 
Table 3. Plasma flow $(\mathrm{ml} / \mathrm{min})$ and net flux ( $\mu \mathrm{mol} / \mathrm{min})$ of amino acids across the liver in lambs fed fresh Sulla (Hedysarum coronarium) without (control) or with Trichostrongylus colubriformis infection (parasite) ${ }^{\star}$ (Least-squares means and associated pooled standard deviations)

\begin{tabular}{|c|c|c|c|c|}
\hline & \multicolumn{2}{|c|}{ Treatment } & \multirow[b]{2}{*}{ SD } & \multirow[b]{2}{*}{$P$} \\
\hline & $\begin{array}{c}\text { Control } \\
(n 6)\end{array}$ & $\begin{array}{c}\text { Parasite } \\
\quad(n 6)\end{array}$ & & \\
\hline Plasma flow† & 256 & 163 & 180 & 0.43 \\
\hline \multicolumn{5}{|l|}{ Non-essential amino acids } \\
\hline Alanine & 40.9 & $29 \cdot 7$ & $19 \cdot 1$ & 0.37 \\
\hline Asparagine & $8 \cdot 7$ & $9 \cdot 0$ & $6 \cdot 4$ & 0.95 \\
\hline Aspartic acid & 0.2 & $2 \cdot 0$ & 4.4 & 0.51 \\
\hline Glutamine & 13.4 & $-2 \cdot 2$ & 27.5 & 0.38 \\
\hline Glutamic acid & $-34 \cdot 2$ & -12.5 & $19 \cdot 2$ & $0 \cdot 11$ \\
\hline Glycine & $43 \cdot 1$ & $42 \cdot 1$ & $19 \cdot 4$ & 0.94 \\
\hline Hydroxyproline & 0.9 & 0.4 & 2.7 & 0.77 \\
\hline Proline & $6 \cdot 7$ & 9.9 & $6 \cdot 1$ & 0.41 \\
\hline Serine & $9 \cdot 7$ & $5 \cdot 1$ & $12 \cdot 6$ & 0.57 \\
\hline \multicolumn{5}{|l|}{ Essential amino acids } \\
\hline Arginine & $5 \cdot 7$ & 8.9 & $7 \cdot 2$ & 0.51 \\
\hline Cysteine & 0.9 & $2 \cdot 0$ & $1 \cdot 8$ & 0.32 \\
\hline Histidine & 7.5 & $4 \cdot 3$ & $1 \cdot 2$ & 0.001 \\
\hline Isoleucine & 0.9 & 4.5 & 3.7 & $0 \cdot 16$ \\
\hline Leucine & 1.8 & $7 \cdot 2$ & $5 \cdot 6$ & 0.16 \\
\hline Lysine & $4 \cdot 8$ & $8 \cdot 2$ & $8 \cdot 7$ & 0.54 \\
\hline Methionine & $3 \cdot 8$ & $2 \cdot 2$ & 1.4 & 0.11 \\
\hline Phenylalanine & $11 \cdot 1$ & $9 \cdot 4$ & $5 \cdot 1$ & 0.60 \\
\hline Threonine & $9 \cdot 5$ & $-2 \cdot 1$ & 4.9 & 0.02 \\
\hline Tyrosine & $7 \cdot 3$ & $8 \cdot 1$ & $4 \cdot 0$ & 0.74 \\
\hline Valine & $-6 \cdot 2$ & $7 \cdot 4$ & $9 \cdot 4$ & 0.05 \\
\hline Non-essential amino acids & $114 \cdot 0$ & 83.5 & $60 \cdot 3$ & 0.83 \\
\hline Essential amino acids & $50 \cdot 8$ & $55 \cdot 8$ & $45 \cdot 2$ & 0.88 \\
\hline Branched-chain amino acids & -3.5 & $19 \cdot 1$ & $18 \cdot 1$ & 0.08 \\
\hline Sulfur amino acids & $4 \cdot 7$ & $4 \cdot 2$ & 1.5 & 0.67 \\
\hline Total amino acids & $192 \cdot 6$ & $127 \cdot 3$ & $109 \cdot 3$ & 0.46 \\
\hline
\end{tabular}

reduction in leucine availability in the portal drainage after 5-7 weeks of dosing with $T$. colubriformis. Higher AA retention within the PDV supports the higher fractional protein synthesis rates observed in the smooth muscle of the small intestine and mesenteric lymph nodes of the parasitised lambs ${ }^{10}$. Reduced AA availability in the portal drainage was the main driver of the reduced release of AA by the TSP in the infected lambs. There was, however, no significant consequence of decreased release of AA by the TSP tissues on hindquarter AA metabolism, as the net flux of AA across the hindquarters was similar between treatments. The pattern of net AA flux across the tissue beds (except for hepatic BCAA fluxes) is in agreement with those presented in the literature for uninfected sheep ${ }^{5,6,23-25}$. The release of BCAA by the liver of control lambs contradicts results published in the literature $^{5,6}$. This is mainly due to a release of valine by the liver of control lambs whilst the other BCAA were taken up by this tissue as expected from the literature. Whilst unlikely, this somewhat unexpected result for valine might be due to changes in hepatic valine metabolism resultant from the $\left[1-{ }^{13} \mathrm{C}\right]$ valine infusion used in the present study. To date, leucine is the only AA for which the net portal flux has been reported for parasitised lambs during a similar stage of infection $^{4}$, consistent with the release reported in the present study.
Table 4. Plasma flow $(\mathrm{ml} / \mathrm{min})$ and net flux $(\mu \mathrm{mol} / \mathrm{min})$ of amino acids across the total splanchnic tissues in lambs fed fresh Sulla (Hedysarum coronarium) without (control) or with Trichostrongylus colubriformis infection (parasite)*

(Least-squares means and associated pooled standard deviations)

\begin{tabular}{|c|c|c|c|c|}
\hline & \multicolumn{2}{|c|}{ Treatment } & \multirow[b]{2}{*}{ SD } & \multirow[b]{2}{*}{$P$} \\
\hline & $\begin{array}{c}\text { Control } \\
(n 6)\end{array}$ & $\begin{array}{c}\text { Parasite } \\
\text { (n6) }\end{array}$ & & \\
\hline Plasma flow & 1687 & 1560 & 434 & 0.63 \\
\hline \multicolumn{5}{|l|}{ Non-essential amino acids } \\
\hline Alanine & -3.6 & $7 \cdot 6$ & $11 \cdot 7$ & 0.14 \\
\hline Asparagine & -6.4 & 0.4 & 3.9 & 0.02 \\
\hline Aspartic acid & -3.5 & -1.9 & 4.4 & 0.55 \\
\hline Glutamine & 43.4 & 52.9 & $23 \cdot 3$ & 0.50 \\
\hline Glutamic acid & $-36 \cdot 2$ & $-34 \cdot 0$ & $20 \cdot 8$ & 0.34 \\
\hline Glycine & $13 \cdot 1$ & $25 \cdot 1$ & $28 \cdot 1$ & 0.48 \\
\hline Hydroxyproline & 1.0 & -0.6 & $3 \cdot 1$ & 0.41 \\
\hline Proline & -9.7 & 2.6 & $8 \cdot 1$ & 0.03 \\
\hline Serine & -5.4 & $-1 \cdot 0$ & $10 \cdot 0$ & 0.47 \\
\hline \multicolumn{5}{|l|}{ Essential amino acids } \\
\hline Arginine & $-4 \cdot 3$ & $8 \cdot 4$ & $9 \cdot 6$ & 0.07 \\
\hline Cysteine & -1.5 & 0.2 & $1 \cdot 1$ & 0.03 \\
\hline Histidine & -1.3 & 3.2 & $3 \cdot 1$ & 0.04 \\
\hline Isoleucine & $-15 \cdot 1$ & $-2 \cdot 7$ & 8.9 & 0.04 \\
\hline Leucine & $-20 \cdot 4$ & -3.4 & 11.5 & 0.03 \\
\hline Lysine & $-11 \cdot 2$ & -0.9 & $9 \cdot 8$ & 0.10 \\
\hline Methionine & -2.7 & 0.9 & $2 \cdot 4$ & 0.03 \\
\hline Phenylalanine & $-2 \cdot 7$ & $2 \cdot 0$ & 2.9 & 0.02 \\
\hline Threonine & $-5 \cdot 1$ & 1.5 & $3 \cdot 8$ & 0.04 \\
\hline Tyrosine & $-4 \cdot 2$ & 2.4 & $4 \cdot 7$ & 0.04 \\
\hline Valine & -26.4 & -8.4 & $17 \cdot 9$ & 0.12 \\
\hline Non-essential amino acids & $-7 \cdot 2$ & 61.0 & $54 \cdot 9$ & 0.06 \\
\hline Essential amino acids & $-91 \cdot 0$ & 11.4 & 62.9 & 0.05 \\
\hline Branched-chain amino acids & -61.9 & -14.5 & 35.9 & 0.05 \\
\hline Sulfur amino acids & $-4 \cdot 2$ & $1 \cdot 1$ & 2.5 & 0.006 \\
\hline Total amino acids & $-96 \cdot 7$ & $72 \cdot 2$ & $107 \cdot 9$ & 0.05 \\
\hline
\end{tabular}

*Positive values represent a net uptake by the tissue, while a negative value represents a net release.

Plasma flow across all measured tissue beds was unaffected by parasitic infection and thus did not contribute to the effects of parasitic infection on the tissue AA flux. In contrast, Yu et $a .^{4}{ }^{4}$ observed a significant increase in both mesenteric and portal plasma flow in parasitised lambs. This might be due to the constant $T$. colubriformis dosing used in that study compared with the single dose used in the present study. Plasma flows in the present study were within the range of those presented elsewhere in the literature for both uninfected ${ }^{6,17,24}$ and parasitised sheep ${ }^{4}$. However, the high CV of MDV plasma flow (in contrast to PDV) among sheep (MDV 20-50\% v. PDV 4-24\%) observed in the present study and others ${ }^{4,6,14,23,24}$ may have masked any effects of infection on MDV AA fluxes. This high variation in the MDV could be attributed to either incomplete mixing of the dye in the blood vessel or movement of the catheter due to peristaltic intestinal contractions ${ }^{23}$.

Decreased PDV AA release during parasitic infection and the lack of effect of the parasite burden on MDV NEAA, BCAA and SAA flux is puzzling. For EAA and total AA, their appearance in the mesenteric drainage decreased (nonsignificantly) and this agrees with the PDV data. Together with increased intestinal AA oxidation, ileal endogenous AA flow (a measure of protein loss in the intestine, included in the MDV and PDV estimates) accounts for most of the 
Table 5. Plasma flow $(\mathrm{ml} / \mathrm{min})$ and net flux ( $\mu \mathrm{mol} / \mathrm{min})$ of amino acids across the hindquarters in lambs fed fresh Sulla (Hedysarum coronarium) without (control) or with Trichostrongylus colubriformis infection (parasite)*

(Least-squares means and associated pooled standard deviations)

\begin{tabular}{|c|c|c|c|c|}
\hline & \multicolumn{2}{|c|}{ Treatment } & \multirow[b]{2}{*}{ SD } & \multirow[b]{2}{*}{$P$} \\
\hline & $\begin{array}{c}\text { Control } \\
(n 6)\end{array}$ & $\begin{array}{c}\text { Parasite } \\
\quad(n 6)\end{array}$ & & \\
\hline Plasma flow & 637 & 502 & 171 & 0.24 \\
\hline \multicolumn{5}{|l|}{ Non-essential amino acids } \\
\hline Alanine & $-13 \cdot 3$ & $-10 \cdot 5$ & $6 \cdot 0$ & 0.47 \\
\hline Asparagine & 1.6 & 0.7 & $2 \cdot 8$ & 0.61 \\
\hline Aspartic acid & -0.5 & $1 \cdot 1$ & 1.0 & 0.06 \\
\hline Glutamine & $-17 \cdot 4$ & -11.9 & $10 \cdot 9$ & 0.44 \\
\hline Glutamic acid & $7 \cdot 2$ & $9 \cdot 3$ & $5 \cdot 2$ & 0.53 \\
\hline Glycine & $-10 \cdot 2$ & -1.6 & $12 \cdot 6$ & 0.31 \\
\hline Hydroxyproline & -0.5 & -0.2 & 0.6 & 0.52 \\
\hline Proline & $-1 \cdot 2$ & 1.0 & 5.5 & 0.54 \\
\hline Serine & 1.5 & $2 \cdot 1$ & 3.7 & 0.81 \\
\hline \multicolumn{5}{|l|}{ Essential amino acids } \\
\hline Arginine & -1.4 & $-1 \cdot 3$ & $4 \cdot 6$ & 0.97 \\
\hline Cysteine & 0.1 & 0.3 & 0.3 & 0.37 \\
\hline Histidine & -0.8 & -0.2 & 2.5 & 0.72 \\
\hline Isoleucine & 2.5 & 1.0 & $5 \cdot 3$ & 0.67 \\
\hline Leucine & $2 \cdot 4$ & $1 \cdot 2$ & $6 \cdot 8$ & 0.77 \\
\hline Lysine & $1 \cdot 7$ & $1 \cdot 3$ & $4 \cdot 8$ & 0.90 \\
\hline Methionine & 0.2 & -0.5 & $2 \cdot 0$ & 0.62 \\
\hline Phenylalanine & -0.4 & -0.8 & $2 \cdot 2$ & 0.80 \\
\hline Threonine & 0.7 & -0.6 & $3 \cdot 1$ & 0.57 \\
\hline Tyrosine & -0.7 & -0.7 & $2 \cdot 4$ & 0.98 \\
\hline Valine & 1.9 & 2.4 & 8.7 & 0.92 \\
\hline Non-essential amino acids & $-35 \cdot 2$ & $-10 \cdot 0$ & $40 \cdot 5$ & 0.38 \\
\hline Essential amino acids & 7.4 & -1.6 & $46 \cdot 8$ & 0.80 \\
\hline Branched-chain amino acids & $6 \cdot 8$ & $4 \cdot 6$ & $20 \cdot 6$ & 0.87 \\
\hline Sulfur amino acids & 0.3 & -0.1 & $2 \cdot 1$ & 0.74 \\
\hline Total amino acids & $-27 \cdot 3$ & -13.5 & 86.5 & 0.83 \\
\hline
\end{tabular}

*Positive values represent a net uptake by the tissue, while a negative value represents a net release.

reduced growth in parasitised lambs ${ }^{4,26}$. Factors other than the high variation in MDV plasma flow discussed above could explain the observed lack of effect of parasitic infection on MDV NEAA and BCAA flux. Changes in tissues other than MDV within the PDV could affect the overall pattern of AA utilisation. The tissues that contribute to the PDV include the rumen, MDV (including the mesenteric lymph nodes), large intestine, pancreas and spleen. Differences between the net flux of AA across the MDV and PDV may indicate partitioning between visceral tissues, such as the rumen, large intestine, pancreas and spleen. As an example, parasitic infection has been shown to increase protein turnover ${ }^{27}$ and mucus production $^{28}$ in the large intestine. In the present study, the net flux of EAA $(P=0.11)$ and total AA $(P=0 \cdot 12)$ but not NEAA across these visceral tissues (PDV data - MDV data) were reduced in the parasitised sheep as for the MDV data.

Among AA, metabolism of glutamine and threonine was affected by the intestinal parasitic infection in both MDV and PDV. Glutamine is a major fuel for the intestinal $\operatorname{mucosa}^{29}$ and immune response $\mathrm{e}^{30,31}$, and is important for intestinal structure, function and metabolism during illness where the mucosal barrier of the intestine is compromised ${ }^{32}$. Intestinal glutamine requirement has also been linked to the activation of the immune response during infection ${ }^{33}$. Thus, the increased uptake of glutamine by the $\operatorname{MDV}(P=0 \cdot 14)$ and PDV $(P<0.05)$ of parasitised lambs may be due to increased requirements by the intestine for the repair of damaged tissue and local immune response. This is supported by increased FSR in ileal smooth muscle and mesenteric lymph nodes in the parasitised lambs. Threonine was taken up by the MDV $(P=0.15)$ and PDV $(P<0.05)$ in parasitised lambs compared with a release in the control lambs, suggesting an increased use of threonine in the intestine. Threonine is present in high concentrations in intestinal protein secretions ${ }^{34-36}$, and as mucus production may have increased as a consequence of parasitic infection ${ }^{26,28,37}$, it is possible that more threonine was utilised for the synthesis of these products.

With the effect of the adult worms on the net AA appearance in the portal drainage, only histidine, threonine and BCAA fluxes were significantly altered across the liver. Threonine was released from the liver of parasitised lambs compared with a net uptake for the control lambs. Threonine is an important EAA for acute-phase protein synthesis in the liver during immune responses ${ }^{33}$ and for intestinal secretions ${ }^{34-36}$. The reason for increased hepatic utilisation of only the BCAA in the parasitised lambs is unclear. As increased hepatic FSR was observed in these parasitised lambs ${ }^{10}$, probably due to the immune response ${ }^{38}$ and/or due to increased hepatic AA oxidation, often seen during inflammation $^{39}$, it should translate to increased utilisation of all AA. This was not the case in the present study.

There were no significant effects of parasitic infection on the net fluxes of oxygen and carbon dioxide across the MDV, PDV, liver, TSP and hindquarters, and the values are consistent with those presented elsewhere in the literature for uninfected sheep ${ }^{40,41}$. Similarly, the net fluxes of ammonia and urea across the tissue beds were unaffected by the presence of a parasitic infection, suggesting no additional requirements for AA or energy for the formation of urea. While glucose metabolism was similar between control and parasitised lambs across the MDV, PDV, liver and TSP, there was a reduction in insulin net flux across the PDV, indicating a reduction in insulin production by the pancreas. There might be a link between reduced insulin secretion by the pancreas (and non-significant reduced TSP release of insulin; $P=0 \cdot 15)$ and the reduction in the utilisation of glucose in the hindquarters of parasitised lambs. This may indicate a sparing of glucose for other tissues, and is in agreement with the similar net flux of lactate across the hindquarters. In the liver, lactate was utilised by parasitised lambs; however, both glucose concentration in the hepatic vein and hepatic fluxes across this tissue were unaffected by parasitism. This suggests that parasitic infection may have increased the dependence on lactate for energy production in the liver.

How can AA metabolism in the hindquarters of control and parasitised lambs be similar despite a lesser amount of AA being released by the TSP into the peripheral circulation? The current data contradict other studies where decreased wool production ${ }^{42}$ and fractional skeletal muscle protein synthesis ${ }^{8}$ were observed in parasitised animals, suggesting a reduced uptake by these tissues. The surgical preparation of the hindquarters where the catheter tip was located approximately $3 \mathrm{~cm}$ from the entry to the right and left iliac vessels means that the blood collected in the vena cava comes from skeletal muscle, skin and bone. In the dog, skeletal muscle 
mass accounts for 88 and $68 \%$ of the leg protein kinetics and blood flow, respectively, while skin and bone accounts for less than $20 \%{ }^{43,44}$. In sheep, the skin probably accounts for a higher proportion of leg protein kinetics and blood flow due to wool growth. However, the hindquarter preparation used in the present study provides an estimate of the overall metabolism of all tissues that composed the hindquarters, but is probably dominated by protein metabolism in its main component, the skeletal muscle. Additionally, the venous outflow of the hindquarters is proximal to where the TSP release intersects with the vena cava. Thus, similar hindquarter AA outflow (vena cava plasma AA concentration $\times$ hindquarter plasma flow) between control and parasitised lambs may mask the lower TSP AA outflow found in our parasitised lambs, as arterial AA inflow to the hindquarters was unaffected between treatments (data not shown).

The significant reduction in live-weight gain in our parasitised animals may be due to decreased body-fat stores. The effects of parasitic infection on body composition have been discussed in a review by Coop \& Kyriazakis $^{3}$, who suggested that nutrient partitioning is prioritised firstly toward immunity, secondly to protein gain and finally to fat deposition. This theory is supported by the reduction in fat deposition observed in parasitised lambs ${ }^{45}$. While in the present study fat deposition was not measured directly, the whole-body water pool which is commonly used to estimate body composition ${ }^{46}$ was reduced in the parasitised lambs ${ }^{10}$. This could explain the reduced live weight observed in the infected lambs, despite similar net AA flux across the hindquarters.

The lambs in the present study were infected with $6000 \mathrm{~T}$. colubriformis larvae per $\mathrm{d}$ for $6 \mathrm{~d}$. The choice to use a singledose method of infection has been discussed in greater detail ${ }^{10}$. Briefly, the single-dose infection has the advantage of measuring the effects of an adult population of parasites on the partitioning of AA and metabolites between tissues without the confounding effects of new larval challenge that a weekly dosing brings. The choice to measure AA fluxes $48 \mathrm{~d}$ post-infection was based on the observations ${ }^{4}$ where significant alterations in protein turnover in the intestinal tissues were observed after 35 to $49 \mathrm{~d}$. It is probable that a larger mobilisation of protein and increased partitioning of AA from the hindquarters to the intestinal and hepatic tissues occurred at an earlier stage of infection, such as the period around maximal faecal egg production (day 26 of infection in the present study).

The results of the present study do not support our hypothesis that more AA are partitioned from the hindquarters to supply the additional AA necessary to repair the damage caused to the intestinal tissues by $T$. colubriformis and to mount an immune response, at least during the established phase of the parasitic infection. The change in AA metabolism observed in the PDV is probably related to shifts in AA requirements within this tissue bed, for example, the ileal smooth muscle and mesenteric lymph nodes. The change in AA requirements of the PDV was largely responsible for the alterations in the flux of AA by the TPS. Large variations in blood flow together with the high variation of responses to parasitic challenge between individuals suggest that measurement of changes in net fluxes of AA and other metabolites between parasitised and control sheep obtained using the arterio-venous technique are probably more appropriate for 
the period of higher inflammation, i.e. the period leading up to peak egg production (up to day 26 post-infection in the present study) with the single dose of parasites or weekly exposure to infective larvae rather than less severe inflammation observed at $48 \mathrm{~d}$ after a single dose of parasite, i.e. when the parasites are adult and well established. Liver fluxes were largely unaffected by an established parasitic infection with the exception of the BCAA, histidine and threonine, probably due to their specific requirements within the liver. The loss of live weight observed in the parasitised lambs may have been due to alterations in the intestinal endogenous protein secretion and/or fat deposition in the parasitised lambs. Trans-organ AA balance data do not provide insights on how the fates of valine and cysteine within the MDV and PDV and liver are affected by an established parasitic infection following a single dose of infective $T$. colubriformis; the kinetics of valine and cysteine in these tissues might provide further insights of their AA metabolism during the established phase of the parasitic infection in growing lambs.

\section{Acknowledgements}

Many thanks to Gordon Reynolds and Brett Guthrie (Massey University, Palmerston North, New Zealand) for assistance with the surgical procedure and to Jason Peters and Mathew Deighton (AgResearch Limited) for technical support throughout the experimental period. The present study was funded by the C. Alma Baker Trust, New Zealand Foundation for Research, Science and Technology and Meat New Zealand. E. N. B. thanks Meat New Zealand for funding her PhD studies.

\section{References}

1. Sykes AR \& Coop RL (1976) Intake and utilisation of food by growing lambs with parasitic damage to the small intestine caused by daily dosing with Trichostrongylus colubriformis larvae. J Agric Sci (Camb) 86, 507-515.

2. van Houtert MFJ, Barger IA, Steel JW, Windon RG \& Emery DL (1995) Effects of dietary protein intake on responses of young sheep to infection with Trichostrongylus colubriformis. Vet Parasitol 56, 163-180.

3. Coop RL \& Kyriazakis I (1999) Nutrition-parasite interaction. Vet Parasitol 84, 187-204.

4. Yu F, Bruce LA, Calder AG, Milne E, Coop RL, Jackson F, Horgan GW \& MacRae JC (2000) Subclinical infection with the nematode Trichostrongylus colubriformis increases gastrointestinal tract leucine metabolism and reduces availability of leucine for other tissues. J Anim Sci 78, 380-390.

5. Lobley GE, Connell A, Lomax MA, Brown DS, Milne E, Calder AG \& Farningham DAH (1995) Hepatic detoxification of ammonia in the ovine liver: possible consequences for amino acid catabolism. Br J Nutr 73, 667-685.

6. Lobley GE, Connell A, Revell DK, Bequette BJ, Brown DS \& Calder AG (1996) Splanchnic-bed transfers of amino acids in sheep blood and plasma, as monitored through use of a multiple U- ${ }^{13}$ C-labelled amino acid mixture. Br J Nutr 75, 217-235.

7. Symons LEA \& Jones WO (1971) Protein metabolism. 1. Incorporation of ${ }^{14} \mathrm{C}$-L-leucine into skeletal muscle and liver proteins of mice and guinea pigs infected with Nematospiroides dubis and Trichostrongylus colubriformis. Exp Parasitol 29, 230-241.
8. Symons LEA \& Jones WO (1978) Protein metabolism 5. Trichostrongylus colubriformis: changes of host body mass and protein synthesis in guinea pigs with light to heavy infections. Exp Parasitol 44, 7-13.

9. Jones WO \& Symons LEA (1982) Protein synthesis in the whole body, liver, skeletal muscle and kidney cortex of lambs infected with Trichostrongylus colubriformis. Int J Parasitol 12, 295-301.

10. Bermingham EN, McNabb WC, Sutherland IA, Sinclair BR, Treloar BP \& Roy NC (2006) Whole-body valine and cysteine kinetics and tissue fractional protein synthesis rates in lambs fed sulla (Hedysarum coronarium) and infected or not infected with adult Trichostrongylus colubriformis. Br J Nutr 96, 28-38.

11. Sykes AR, Poppi DP \& Elliot DC (1988) Effect of concurrent infection with Ostertagia circumcincta and Trichostrongylus colubriformis on the performance of growing lambs consuming fresh forages. J Agric Sci (Camb) 110, 531-541.

12. Bermingham EN (2004) The metabolic cost of an intestinal parasite infection on amino acid kinetics in sheep fed fresh forages. PhD Thesis, Massey University, New Zealand.

13. Huntington GB, Reynolds CK \& Stroud BH (1989) Techniques for measuring blood flow in splanchnic tissues of cattle. J Dairy Sci 72, 1583-1595.

14. Ortigues I \& Durand D (1995) Adaptation of energy metabolism to undernutrition in ewes. Contribution of portal-drained viscera, liver and hindquarters. Br J Nutr 73, 209-226.

15. Whitlock H (1948) Some modifications of the McMaster helminth egg-counting technique and apparatus. J Counc Sci Ind Res Aust 21, 177-180.

16. Sutherland IA, Leathwick DM, Green R, Brown AE \& Miller CM (1999) The effect of continuous drug exposure on the immune response to Trichostrongylus colubriformis in sheep. Vet Parasitol 80, 261-271.

17. Wester TJ, Lobley GE, Birnie LM \& Lomax MA (2000) Insulin stimulates phenylalanine uptake across the hind limb in fed lambs. J Nutr 130, 608-611.

18. Bidlingmeyer BA, Cohen SA \& Tarvin TL (1984) Rapid analysis of amino acids using pre-column derivatisation. J Chromatogr 336, 93-104.

19. Gaitonde MK (1967) A spectrophotometric method for the direct determination of cysteine in the presence of other naturally occuring amino acids. Biochem $J$ 104, 627-633.

20. Flux DS, Mackenzie DDS \& Wilson GF (1984) Plasma metabolite and hormone concentration in Friesian cows of differing genetic merit measured at two feeding levels. Anim Prod 38, 377-384.

21. Katz ML \& Bergman EN (1969) Simultaneous measurements of hepatic and portal venous blood flow in the sheep and $\operatorname{dog}$. Am J Physiol 216, 946-952.

22. Sutherland IA, Brown AE, Green RS, Miller CM \& Leathwick DM (1999) The immune response of sheep to larval challenge with Ostertagia circumcinta and O. ostertagi. Vet Parasitol 84, 125-135.

23. MacRae JC, Bruce LA, Brown DS, Farningham DAH \& Franklin M (1997) Absorption of amino acids from the intestine and their net flux across the mesenteric- and portal-drained viscera of lambs. J Anim Sci 75, 3307-3314.

24. Piccioli Cappelli F, Seal CJ \& Parker DS (1997) Glucose and $\left[{ }^{13} \mathrm{C}\right]$ leucine metabolism by the portal drained viscera of sheep fed on dried grass with acute intravenous and intraduodenal infusions of glucose. Br J Nutr 78, 931-946.

25. Hoskin SO, Savary IC, Zuur G \& Lobley GE (2001) Effect of feed intake on ovine hindlimb protein metabolism based on thirteen amino acids and arterio-venous techniques. Bri J Nutr 86, $577-585$.

26. Yu F, Bruce LA, Coop RL \& MacRae JC (1999) Losses of non-resorbed endogenous leucine from the intestine of lambs exposed to the intestinal parasite Trichostrongylus colubriformis. In Book of Abstracts of the VIIIth International 
Symposium on Protein Metabolism and Nutrition [GE Lobley, A White, JC MacRae, editors], p. 48. UK: Aberdeen, 1-4 September 1999.

27. Symons LEA \& Jones WO (1983) Intestinal protein synthesis in guinea pigs infected with Trichostrongylus colubriformis. Int $J$ Parasit 13, 309-312.

28. Cheema KJ \& Scofield AM (1982) Scanning electron microscopy of the intestines of rats infected with Nippostrongylus brasiliensis. Int J Parasit 12, 199-205.

29. Souba WW (1991) Glutamine: a key substrate for the splanchnic bed. Ann Rev Nutr 11, 285-308.

30. Wu G, Field CJ \& Marliss EB (1991) Glutamine and glucose metabolism in rat splenocytes and mesenteric lymph node lymphocytes. Am J Physiol 260, E141-E147.

31. Calder PC (1995) Fuel utilization by cells of the immune system. Proc Nutr Soc 54, 65-82.

32. Souba WW, Klimburg VS, Plumley DA, Salloum RM, Flynn TC, Bland KI \& Copeland EM (1990) The role of glutamine in maintaining a healthy gut and supporting the metabolic response to injury and infection. J Surgical Res 48, 383-391.

33. Obled C (2002) Amino acid requirement in inflammatory states. In Amino Acids: Meat, Milk and More! CSAS - Symposium SCSA, pp. 55-63 [H Lapierre and DR Ouellet, editors]. Canadian Society for Animal Science, Quebec, Canada.

34. MacRae JC \& Lobley GE (1991) Physiological and metabolic implications of conventional and novel methods for the manipulation of growth and production. Livest Prod Sci 27, 43-59.

35. Roberton AM, Rabel B, Harding CA, Tasman-Jones C, Harris PJ \& Lee SP (1991) Use of the ileal conduit as a model for studying human small intestinal mucus glycoprotein secretion. Am J Physiol 261, G728-G734.

36. van Klinken BJW, Einerhand AWC, Büller HA \& Dekker J (1998) Strategic biochemical analysis of mucins. Anal Bioch 265, $103-116$.
37. Grimble RF (1990) Nutrition and cytokine action. Nutr Res Rev 3, $193-210$.

38. Stephenson LS, Pond WG, Nesheim MC, Krook LP \& Crompton DWT (1980) Ascaris suum: nutrient absorption, growth, and intestinal pathology in young pigs experimentally infected with 15-day-old larvae. Exp Parasit 49, $15-25$.

39. Southorn BG \& Thompson JR (1987) Hepatic serine and alanine metabolism during endotoxin-induced fever in sheep. Can J Vet Res 51, 319-325.

40. Bird AR, Chandler KD \& Bell AW (1981) Effects of exercise and plane of nutrition on nutrient utilization by the hind limb of the sheep. Aust J Biol Sci 34, 541-550.

41. Pell JM \& Bergman EN (1983) Cerebral metabolism of amino acids and glucose in fed and fasted sheep. Am J Physiol 244, E282-E289.

42. Leyva V, Henderson AE \& Sykes AR (1982) Effect of daily infection with Ostertagia circumcincta larvae on food intake, milk production and wool growth in sheep. J Agric Sci (Camb) 99, 249-259.

43. Biolo G, Gastaldelli A, Zhang XJ \& Wolfe RR (1994) Protein synthesis and breakdown in skin and muscle: a leg model of amino acids kinetics. Am J Physiol 267, E467-E474.

44. Biolo G, Declan-Flemming RY, Maggi SP \& Wolfe RR (1995) Transmembrane transport and intracellular kinetics of amino acids in human skeletal muscle. Am J Physiol 268, E75-E84.

45. Coop RL, Sykes AR \& Angus KW (1982) The effect of three levels of intake of Ostertagia circumcincta larvae on growth rate, food intake and body composition of growing lambs. J Agric Sci (Camb) 98, 247-255.

46. Searle TW (1970) Body composition in lambs and young sheep and its prediction in vivo from tritiated water space and body weight. J Agric Sci (Camb) 74, 357-362. 